\title{
Clinical checklists in the selection of mentally retarded males for molecular screening of fragile $X$ syndrome
}

\author{
Denise M. Christofolini ${ }^{1}$, Monica V.N. Lipay ${ }^{1}$, Marco Antonio P. Ramos ${ }^{1}$, Silvia S. Costa ${ }^{2}$, \\ Fernanda T.S. Bellucco ${ }^{1}$, Sintia I. Nogueira ${ }^{1}$, Leslie D. Kulikowski ${ }^{1}$, Décio Brunoni ${ }^{1}$ \\ and Maria Isabel Melaragno ${ }^{1}$ \\ ${ }^{1}$ Universidade Federal de São Paulo, São Paulo, SP, Brazil. \\ ${ }^{2}$ Departamento de Genética e Biologia Evolutiva, Instituto de Biociências, Universidade de São Paulo, \\ São Paulo, SP, Brazil.
}

\begin{abstract}
Fragile $\mathrm{X}$ syndrome is the most frequent cause of inherited mental retardation. The phenotype in this syndrome is quite variable and less conspicuous in younger patients, making clinical diagnosis difficult and thus making molecular diagnosis necessary. The use of clinical checklists in mentally retarded individuals can help selecting patients to be given priority in the molecular investigation for the fragile-X mutation in the FMR1 gene. We evaluated two clinical checklists in a sample of 200 Brazilian male patients with mental retardation. The highest scores in the two checklists concentrated among the 19 males (9.5\%) found to carry full mutations. Our results confirm the importance of fragile-X checklists as a clinical tool in the study of mentally retarded patients.
\end{abstract}

Key words: FMR1 gene, fragile X syndrome checklist, molecular methods, X-linked mental retardation.

Received: January 30, 2007; Accepted: May 10, 2007.

\section{Introduction}

Mental retardation is one of the most common human disorders, affecting around $3 \%$ of the world population. It becomes evident during the school years, when it manifests as developmental delay (Toniolo, 2000). It has been long recognized that there is an excess of males of about $30 \%$ over females among mentally retarded individuals, and this excess is in part explained by mutations in X-linked genes (Ropers and Humel, 2005). Thus, a common situation in clinical genetic centers is large number of mentally retarded male patients with no chromosomal alteration or other recognizable cause for their condition.

Fragile $\mathrm{X}$ syndrome is the most frequent cause of inherited mental retardation, with a prevalence of 1:4000 to 1:6000 for males and $1: 8000$ to $1: 9000$ for females (Crawford et al., 2001). In almost all cases, the fragile $\mathrm{X}$ syndrome results from a dynamic mutation, characterized by an abnormal expansion of the CGG repeat at the 5' untranslated region (UTR) of the fragile-X mental retardation gene $(F M R 1)$. This expansion, which is associated with the methylation of the adjacent $\mathrm{CpG}$ island, leads to the absence of the FMRP protein (Pieretti et al., 1991) and, conse-

Send correspondence to Maria Isabel Melaragno. Universidade Federal de São Paulo, Rua Botucatu 740, 04023-900 São Paulo, SP, Brazil. E-mail: melaragno.morf@unifesp.br. quently, fragile $\mathrm{X}$ syndrome. The discovery of the FMR1 mutation in 1991 allowed the development of reliable diagnostic methods (Fu et al., 1991; Oberlé et al., 1991). Two approaches are generally used, Southern blot analysis and the polymerase chain reaction (PCR). Southern blotting is the golden standard method for laboratory diagnosis because it not only allows the accurate identification of the full mutation and the premutation state but also reveals the methylation status and can detect all size ranges of the mutation. Southern blot analysis is, however, expensive and time-consuming and PCR is cheaper and has a shorter turnaround time, although the efficiency of PCR is inversely related to the number of CGG repeats and it is only accurate in the sizing of alleles in the normal and premutation ranges.

The fragile $\mathrm{X}$ phenotype is quite variable but its main and most consistent clinical feature is mental retardation but since physical and behavioral characteristics vary depending on age and sex (Hagerman et al., 1991) clinical diagnosis is difficult and makes molecular diagnosis necessary. Although mental retardation is a common disorder, providing fragile $\mathrm{X}$ molecular analysis to all patients would not only be prohibitively costly but, in many cases, unnecessary, a practical alternative being to select patients with a high probability of being affected by fragile $X$ syndrome for further molecular analysis. Several fragile-X 
checklists for identifying males who might be affected by this syndrome have been published (Butler et al., 1991; Hagerman, 1991; Laing et al., 1991; Arvio, 1997; De Vries, 1999; Limprasert, 2000; Maes, 2000). These checklists are based on the most common characteristics of the syndrome. According to Mandel and Biancalana (2004), the use of checklists to select patients that are likely to have fragile $\mathrm{X}$ syndrome may reduce by 60 to $80 \%$ the number of individuals submitted to molecular evaluation, thus avoiding waste and increasing the positive diagnosis rate.

During the research reported in this paper we used the checklists published by Butler et al. (1991) and Laing et al. (1991) and evaluated their selective power by comparing the results of molecular diagnosis with the checklist scores for 200 mentally retarded patients.

\section{Material and Methods}

\section{Study group}

In this study we enrolled 200 male Brazilian patients between 3 and 36 years old $($ mean $=11.3$ y) presenting mental retardation and attending the Hospital São Paulo, Brazil, as outpatients. All the males had normal karyotypes, and males with known dysmorphic and metabolic syndromes with mental retardation were not enrolled. The Research Ethics Committee at UNIFESP approved this study and informed consent was obtained from the patients' parents.

\section{Checklist evaluation}

The checklist proposed by Butler et al. (1991) consists of 15 items: mental retardation, large ears, large testes, hyperactivity, family history of mental retardation or autism, short attention span, tactile defensiveness, hyperextensible finger joints, perseverative speech, hand-flapping, hand biting, poor eye contact, Sydney palmar crease, plantar crease and pale blue eyes.
Laing et al. (1991) proposed a clinical score based on five items: family history of intellectual handicap, face length, ear configuration, personality (lack of eye contact followed by friendliness and verbosity with echolalic speech patterns) and body habits (slim physique with tall stature, rounded shoulders, hyperextensible finger joints, lack of body hair or an obese physique with feminine distribution of body fat and stria).

For both lists, each item received a score of 0 if never present, 1 if present in the past or if questionable or borderline or 2 if definitely present. The maximum score for an individual varies from 0 to 30 on Butler's checklist and from 0 to 10 on Laing's checklist, the scores being divided into the intervals shown in Table 1. The same clinical geneticist applied the checklists to all the males.

\section{Molecular analysis}

Genomic DNA was obtained from peripheral blood leukocytes by the salting-out method described by Lahiri and Nurnberger (1991), with modifications. DNA samples were analyzed using the PCR according to Haddad et al. (1996). In this method genomic DNA is amplified by one forward and two reverse primers in two combinations, one pair of primers flanking the trinucleotide repeat region amplifies a fragment containing the variable CGG region while the other pair of primers amplifies a smaller $223 \mathrm{bp}$ fragment of the CGG region used as an internal control. The conditions were established in such a manner that full mutations would fail to amplify the variable region, i.e. males with the normal gene showed two amplified bands while those with the fully mutated gene showed only the control band. The PCR products were separated by electrophoresis on a proprietary acrylamide gel (GeneGel Excel, GE Health Care ${ }^{\circledR}$, Sweeden) and silver-stained according to Santos et al. (1993). Three reactions were performed for each patient. All positive results for FMR1 mutations were validated by Southern blot analysis according to Mingroni-Netto et al. (1996).

Table 1 - Accumulated score frequency distribution for mentally retarded males $(\mathrm{n}=200)$ who showed a normal (181) or mutated (19) fragile X mental retardation gene (FMRI) and had been scored for fragile X syndrome according to the checklists of Butler et al. (1991) and Laing et al. (1991). For each score interval the difference between accumulated percentage (Ac. \%) values was calculated as the Ac. \% for males with a normal $F M R 1$ gene minus the Ac. $\%$ for males with a mutated FMRI gene. Statistical analysis showed significantly higher Butler $\left(\chi^{2}=33.28, p<0.001\right)$ and Laing $\left(\chi^{2}=14.68\right.$, $\mathrm{p}<0.001$ ) scores for males with the mutant gene compared with males with the normal gene.

\begin{tabular}{|c|c|c|c|c|c|c|c|c|c|c|}
\hline \multirow[b]{2}{*}{ Parameters } & \multicolumn{7}{|c|}{ Butler score intervals } & \multicolumn{3}{|c|}{ Laing score intervals } \\
\hline & 2 to 5 & 6 to 9 & 10 to 13 & 14 to 17 & 18 to 21 & 22 to 25 & 26 to 29 & 2 to 4 & 5 to 7 & 8 to 10 \\
\hline \multicolumn{11}{|l|}{ Normal FMR1 gene $(\mathrm{n}=181$ males $)$} \\
\hline Accumulated number of males & 0 & 8 & 32 & 109 & 164 & 180 & 181 & 23 & 120 & 181 \\
\hline Accumulated $\%$ of males & 0 & 4.42 & 17.68 & 60.22 & 90.61 & 99.45 & 100 & 12.71 & 66.30 & 100 \\
\hline \multicolumn{11}{|l|}{ Mutated FMR 1 gene $(\mathrm{n}=19$ males $)$} \\
\hline Accumulated number of males & 0 & 0 & 1 & 3 & 4 & 13 & 19 & 0 & 4 & 19 \\
\hline Accumulated $\%$ of males & 0 & 0 & 5.26 & 15.79 & 21.05 & 68.42 & 100 & 0 & 21.05 & 100 \\
\hline Difference between accumulated $\%$ values & 0 & 4.42 & 12.42 & 44.43 & 69.56 & 31.03 & 0 & 12.71 & 45.25 & 0 \\
\hline
\end{tabular}




\section{Statistical analysis}

The males were distributed into two groups according to their molecular results, as negative for the full mutation (normal FMR1) or positive for the full FMR1 mutation (mutant FMR1). Clinical scores of the two groups were compared using the Kolmogorov-Smirnov test (Siegel and Castellan, 2006).

\section{Results}

The PCR showed that $181(90.5 \%)$ of the males were carrying a normal FMR1 gene while $19(9.5 \%)$ had a fully mutated FMR1 gene, confirmed by Southern blotting. No premutation was detected.

Scores varied from 6 to 28 on the Butler checklist and from 2 to 10 on the Laing checklist, the distribution of males with the normal FMR1 gene and those with the full FMR1 mutation according to their Butler or Laing scores being presented in Table 1. For males with normal FMR1 genes the Butler score ranged from 6 to 26 and the Laing score from 2 to 10 , while for males with a mutated FMR1 gene (i.e. with fragile $\mathrm{X}$ syndrome) the Butler score ranged from 12 to 28 and the Laing score from 5 to 10 . Butler and Laing scores were significantly higher $\left(\chi^{2}=33.28\right.$, $\mathrm{p}<0.001)$ and $\left(\chi^{2}=14.68, \mathrm{p}<0.001\right)$, respectively, for males with fragile $\mathrm{X}$ syndrome than for those without fragile $\mathrm{X}$ syndrome. The largest differences between accumulated frequencies of mutated and normal males were at the 18 to 21 Butler score interval ( $\operatorname{Dmax}=0.69555)$, and at the 5 to 7 Laing score interval $(\operatorname{Dmax}=0.4525)$, which can be considered as the cutoff points above which the presence of fragile $\mathrm{X}$ syndrome is probable (Table 1).

\section{Discussion}

Because of the high frequency of fragile $\mathrm{X}$ syndrome among mentally retarded males, checklists have been proposed to help identify males who should be submitted to laboratory tests. We used the Butler and the Laing checklists to study 200 mentally retarded male patients and found that scores were significantly higher for males with the full FMR1 mutation than for males with a normal FMR1 gene, confirming the utility of checklists for screening for Fragile $\mathrm{X}$ syndrome.

There are no cutoff points in either the Butler or the Laing checklist, so to make these checklists more useful and simpler to apply we determined a cutoff point based on the molecular results for our sample of males with normal or mutated FMR 1 genes. Of the 200 males tested, the molecular techniques identified a total of 19 males $(9.5 \%)$ carrying the full FMR1 gene mutation and our Butler checklist results showed that if we had used molecular techniques to investigate only males with a score higher than, or equal to, the Butler score (18) with the greatest difference between the number of males with a normal gene and the number of males with a mutated gene we would have had to perform molecular tests not on 200 males but on only 88 males, 16 of which (18.2\% of 88 ) would have been positive for fragile $\mathrm{X}$ syndrome. Of the 122 males ( $61 \%$ of the total) classified with a Butler score lower than 18 only $3(2.5 \%$ of 122$)$ had a fully mutated gene, so if we had used a cutoff score of below 18 we would have had to assess more males to detect a similar number of males with a mutated gene as would have been the case if we had used a cutoff point of 18 or higher. In fact, we would have had to test 192 of the males $(96 \%$ of the total) to avoid missing any a mutated gene, i.e. almost the all the males in the study. Of course, in actuality, all the males enrolled in this study were tested using molecular techniques, but our data shows that the judicious use of appropriate Butler scale cutoff points can result in effective screening and reduce the number of molecular investigations needed

There were 177 males ( $88.5 \%$ of the total) who had a Laing score of 5 or higher, for which we found the highest difference between the number of males with a normal gene and the number of males with a mutated gene. This group of 177 males contained all 19 males (10.73\% of 177) which molecular techniques had shown to have a fully mutated FMR1 gene The 177 males with the highest Laing scores was over twice the 88 with a Butler score of 18 or over, indicating that the Butler checklist would result in a smaller number of candidates for molecular evaluation and has better applicability in clinical management.

Some of the males who carried a full FMRl gene mutation presented intermediate or low scores on the checklists. For the younger males this could have been because the phenotype tends to become more evident with age, usually after puberty, but this is not the only reason since one male was 18 years old but did not present any syndromic features.

In some of the males with severe mental retardation, characteristics related to speech were difficult to evaluate since they did not speak and this was important for evaluation using the Laing checklist because one of the five characteristics evaluated is personality and this is related to speech. This fact could have caused the low Laing scores found in patients with positive molecular results.

The Butler checklist considers 15 characteristics, some of which, such as pale blue eyes, were uncommon in our population. Pale blue eyes is not a feature of fragile $X$ syndrome but was associated to the syndrome because the early patients diagnosed were of European origin. This fact points to the need for developing a checklist based on characteristics which are more common in Brazilian patients.

In our sample, most (15 out of 19) of the males identified with fragile $\mathrm{X}$ syndrome had a family history of mental retardation and there was a significant association $(\mathrm{p}<0.001)$ between these two factors. Neri et al. (1994) reported that one third of patients with familial X-linked mental retardation have fragile $\mathrm{X}$ syndrome. In our sample 
15 of the 60 males $(25 \%)$ with familial mental retardation presented the fragile $\mathrm{X}$ syndrome.

Given the high frequency of mentally retarded males in the general population, the implementation of checklist screening methods can help reduce the number of patients selected for molecular analysis, with a higher percentage of positive results and no significant loss of false-negative results.

\section{Acknowledgments}

This research was supported by the Brazilian agencies Fundação de Amparo à Pesquisa do Estado de São Paulo (FAPESP) and Coordenação de Aperfeiçoamento de Pessoal de Nível Superior (CAPES). We thank Ms. Laurinda de Fátima P. C. Baptista for technical assistance and Drs Yara Juliano and Neil Ferreira Novo (UNISA) for assistance with the statistical analysis.

\section{References}

Arvio M, Peippo M and Simola KOJ (1997) Applicability of a checklist for clinical screening of the fragile $\mathrm{X}$ syndrome. Clin Genet 52:211-215.

Butler MG, Mangrum T, Gupta R and Singhi DN (1991) A 15-item checklist for screening mentally retarded males for fragile X syndrome. Clin Genet 39:347-354.

Crawford DC, Acuna JM and Sherman S (2001) FMR1 and the fragile X syndrome: Human genome epidemiology review. Genet Med 5:359-571.

de Vries BB, Mohkamsing S, van den Ouweland AM, Mol E, Gelsema K, van Rijn M, Tibben A, Halley DJ, Duivenvoorden HJ, Oostra BA, et al. (1999) Screening for the fragile $\mathrm{X}$ syndrome among the mentally retarded: A clinical study. The Collaborative Fragile X Study Group. J Med Genet 36:467-470.

Fu YH, Kuhl DP, Pizzuti A, Pieretti M, Sutcliffe JS, Richards S, Verkerk AJ, Holden JJ, Fenwick Jr RG, Warren ST, et al. (1991) Variation of the CGG repeat at the fragile X site results in genetic instability: Resolution of the Sherman paradox. Cell 67:1047-58.
Haddad LA, Mingroni-Neto RC, Vianna-Morgante AM and Penna SDJ (1996) A PCR-based test suitable for screening for fragile $\mathrm{X}$ syndrome among mentally retarded males. Hum Genet 97:808-812.

Hagerman RJ, Amiri K and Cronister A (1991) Fragile X checklist. Am J Med Genet 38:283-287.

Lahiri DK and Nurnberger Jr JI (1991) A rapid non-enzymatic method for the preparation of HMW DNA from blood for RFLP studies. Nucleic Acids Res 19:5444.

Laing S, Partington M, Robinson H and Turner G (1991) Clinical screening score for fragile X (Martin - Bell) syndrome. Am J Med Genet 38:256-259.

Mandel JL and Biancalana V (2004) Fragile X mental retardation syndrome: From pathogenesis to diagnostic issues. Growth Hormone \& IGF Research 14 Suppl A:S158-S165.

Mingroni-Netto RC, Haddad LA and Vianna-Morgante AM (1996) The number of CGG repeats of the FMR1 locus in premutated and fully mutated heterozygotes and their offspring: Implications for the origin of mosaicism. Am J Med Genet 64:270-273.

Neri G, Chiurazzi P and Pomponi MG (1994) The molecular diagnosis of fragile $\mathrm{X}$ and $\mathrm{X}$ linked mental retardation syndromes. Int Pediat 9:205-208.

Oberle I, Rousseau F, Heitz D, Kretz C, Devys D, Hanauer A, Boue J, Bertheas MF and Mandel JL (1991) Instability of a 550-base pair DNA segment and abnormal methylation in fragile X syndrome. Science 252:1097-102.

Pieretti M, Zhang F and Fu Y-H (1991) Absence of expression of the FMR1 gene in fragile X syndrome. Cell 66:817-822.

Ropers HH and Hamel BC (2005) X-linked mental retardation. Nat Rev Genet 6:46-57.

Santos FR, Pena SD and Epplen JT (1993) Genetic and population study of a Y-linked tetranucleotide repeat DNA polymorphism with a simple non-isotopic technique. Hum Genet 90:655-656.

Siegel S and Castellan NR (2006) Estatística Não-Paramétrica para Ciências do Comportamento. 2nd edition. Artmed, Porto Alegre, $448 \mathrm{pp}$.

Toniolo D (2000) In search of the MRX genes. Am J Med Genet 97:221-227.

Associate Editor: Paulo A. Otto 